\title{
Whale shark Rhincodon typus populations along the west coast of the Gulf of California and implications for management
}

\author{
Dení Ramírez-Macías ${ }^{1,2, *}$, Abraham Vázquez-Haikin ${ }^{3}$, Ricardo Vázquez-Juárez ${ }^{1}$ \\ ${ }^{1}$ Centro de Investigaciones Biológicas del Noroeste, Mar Bermejo 195, Col. Playa Palo de Santa Rita, La Paz, \\ Baja California Sur 23096, Mexico \\ ${ }^{2}$ Tiburón Ballena México de Conciencia México, Manatí 4802, Col. Esperanza III, La Paz, Baja California Sur 23090, Mexico \\ ${ }^{3}$ Asociación de Pesca Deportiva y Ecoturismo de Bahía de los Ángeles, Domicilio conocido Bahía de los Ángeles, \\ Baja California 22980, Mexico
}

\begin{abstract}
We used photo-identification data collected from 2003 through 2009 to estimate population structure, site fidelity, abundance, and movements of this species along the west coast of the Gulf of California to make recommendations for effective conservation and management. Of 251 whale sharks identified from 1784 photographs, 129 sharks were identified in Bahía de Los Ángeles and 125 in Bahía de La Paz. Only juveniles (mostly small) were found in these 2 bays. At Isla Espíritu Santo, we identified adult females; at Gorda Banks we identified 15 pregnant females. High re-sighting rates within and across years provided evidence of site fidelity among juvenile sharks in the 2 bays. Though the juveniles were not permanent residents, they used the areas regularly from year to year. A proportion of the juveniles spent days to a month or more in the coastal waters of the 2 bays before leaving, and periods of over a month outside the study areas before entering the bays again. Additionally, 26 juveniles migrated between Bahía de Los Ángeles and Bahía de La Paz. Pregnant females aggregated for a few days in oceanic waters at Isla Espíritu Santo and Gorda Banks, but no re-sightings occurred between years. The presence of pregnant females and small juveniles $(2 \mathrm{~m})$ suggests the presence of a nursery near the 2 far offshore areas. These 4 localities are important for conservation of this endangered species.
\end{abstract}

KEY WORDS: Abundance $\cdot$ Fidelity $\cdot$ Movements $\cdot$ Population structure Resale or republication not permitted without written consent of the publisher

\section{INTRODUCTION}

Whale sharks Rhincodon typus are epipelagic, with worldwide distribution in tropical and subtropical seas (Compagno 1984, Wolfson 1986, Stevens 2007). Global abundance of whale sharks is unknown, although declines at some localities are linked to targeted fisheries (CITES 2002). As a result, whale sharks are globally listed as 'Vulnerable' by the IUCN and included in Appendix II of CITES and the red list in Mexico in 2001 (DOF 2002). Whale sharks are fundamentally vulnerable to exploitation and other impacts related to their life history, including late matu- ration, extended longevity, and small population size (Colman 1997, Wintner 2000, CITES 2002).

The spot pattern of a whale shark is unique to each and is an effective marker for capture-mark-recapture studies (Taylor 1994, Arzoumanian et al. 2005). Underwater photographs of sharks, combined with photo-comparison software, are used to identify resighted sharks, which, in turn, contribute to estimates of population size, age structure, sex ratio, site fidelity, and trends in abundance. This technique has been applied to whale shark aggregations off Western Australia (Meekan et al. 2006, Holmberg et al. 2008, 2009), Belize (Graham \& Roberts 2007), the 
Seychelles (Rowat et al. 2009), the Maldives (Riley et al. 2010), Djibouti (Rowat et al. 2011), and Isla Holbox, adjacent to the northern tip of the Yucatan Peninsula (Ramírez-Macías et al. 2012). These studies show that most aggregations are composed of juvenile male whale sharks ( $<8 \mathrm{~m}$ length). Most photographs identify sharks that are sighted only once, indicating a preponderance of transient sharks; only a small proportion of sightings consists of returning sharks, sometimes after periods of more than a decade (Meekan et al. 2006).

Studies of whale shark migrations generally depend on remote tracking (e.g. Eckert \& Stewart 2001). Opportunistic identification of individuals provides data that is used to create realistic migration models (Whitehead 2001).

Whale sharks have been recorded in the Gulf of California since 1858 (Wolfson 1987). Eckert \& Stewart (2001) conducted a telemetry study to document migrations of whale sharks in the Gulf of California and the northern Pacific Ocean; apparently 1 tagged whale shark showed this movement, suggesting that whale sharks range widely, at least in the North Pacific Ocean, and perhaps make migrations that take several years to complete. Population genetics indicate that whale sharks in the Gulf of California are genetically related; movements of 2 sharks between Bahía de Los Ángeles and Bahía de La Paz (separated by $700 \mathrm{~km}$ ) have been seen as well as the return of 4 individuals to the same area in the follow-

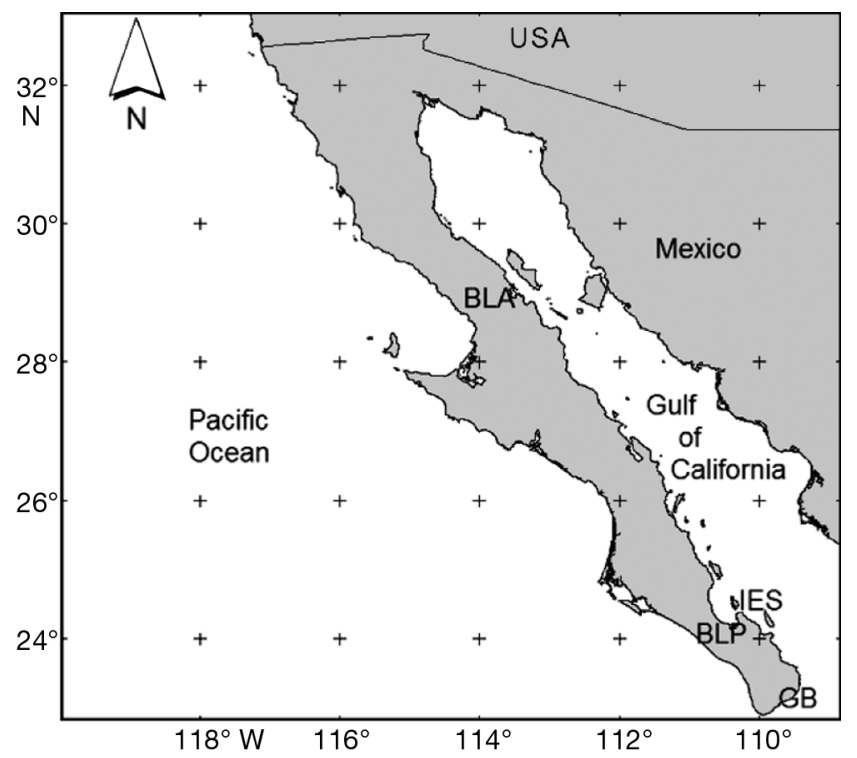

Fig. 1. Rhincodon typus. Aggregation area of whale sharks on the west side of the Gulf of California. BLA: Bahía de Los Ángeles; BLP: Bahía de La Paz; GB: Gorda Banks; IES: Isla Espíritu Santo ing year (Ramírez-Macías et al. 2007). Also, whale sharks segregate themselves by sex and size; pregnant females and small juveniles $(2 \mathrm{~m})$ in 2 relatively small areas suggest nearby nursery areas (RamírezMacías et al. 2007). Understanding seasonality, abundance, population structure, and home range of the population in aggregation areas is needed for effective management of whale sharks.

The present study reports on the use of the photoidentification method to estimate annual abundance, population structure, site affinity, and regional movements of whale sharks that aggregate in Bahía de Los Ángeles, Bahía de La Paz, offshore Isla Espíritu Santo, and near the seamounts forming Gorda Banks east of San Jose del Cabo. We discuss our findings according to the implications for management.

\section{MATERIALS AND METHODS}

\section{Study site and data collection}

The data on whale sharks Rhincodon typus were collected mainly by researchers and trained volunteers from 2003 through 2009 at 4 sites on the western side of the Gulf of California (Fig. 1). In Bahía de Los Ángeles, 3 short-term monitoring programs were carried out in October 2003, from 2004 to 2007, and from May through November in 2008 and 2009. In Bahía de La Paz, the surveys were conducted during the aggregation season from 2003 through 2009. During the early surveys, our field work was limited to the same time as the previous aggregation season, August through November (Wolfson 1987, Clark \& Nelson 1997, Ketchum 2003). In the final 2 seasons, we surveyed from August until no whale sharks had been sighted fot at least $1 \mathrm{wk}$. During all aggregation seasons, we carried out at least 1 survey each week during each season. The surveys from 2004 through 2009 at Isla Espíritu Santo were made in May and June; in 2009 a spotter airplane was used to find pregnant females in this area (Wolfson 1987, Clark \& Nelson 1997, Ketchum 2003). Gorda Banks was visited when local fishermen informed us that whale sharks were present $(2003,2005,2006,2007)$. Table 1 summarizes the effort made at the 4 localities.

At each encounter with a whale shark, gender was determined by the presence of claspers on males. Claspers are short, soft, and smooth in sexually immature males, but quickly grow and calcify during maturation (Norman \& Stevens 2007); in adult sharks, they often appear rough and abraded (Joung \& Chen 1995). We recorded the form of the claspers to distin- 
Table 1. Rhincodon typus. Summary of photo-identification (left side only) of whale sharks. Totals for sharks identified do not include re-sightings. BLP: Bahía de La Paz; BLA: Bahía de Los Ángeles; GB: Gorda Banks; IES: Isla Espíritu Santo; -: no survey conducted

\begin{tabular}{|c|c|c|c|c|c|c|c|c|c|}
\hline \multirow[t]{2}{*}{ Year } & \multicolumn{5}{|c|}{$\longrightarrow$ Surveys } & \multicolumn{4}{|c|}{ Sharks identified } \\
\hline & Total & BLP & BLA & GB & IES & BLP & BLA & GB & IES \\
\hline 2003 & 21 & 10 & 8 & 3 & - & 0 & 12 & 5 & - \\
\hline 2004 & 16 & 6 & 3 & - & 7 & 8 & 8 & - & 0 \\
\hline 2005 & 58 & 31 & 15 & 3 & 9 & 30 & 0 & 0 & 0 \\
\hline 2006 & 29 & 8 & 3 & 11 & 7 & 19 & 4 & 10 & 0 \\
\hline 2007 & 34 & 13 & 6 & 5 & 10 & 20 & 10 & 0 & 1 \\
\hline 2008 & 54 & 29 & 18 & - & 7 & 33 & 40 & - & 1 \\
\hline 2009 & 82 & 53 & 25 & - & 4 & 54 & 73 & - & 6 \\
\hline Total & 304 & 150 & 78 & 22 & 44 & 125 & 129 & 15 & 8 \\
\hline
\end{tabular}

guish immature from mature males. It was not possible to determine sexual maturity in females by observation, except when the sharks were obviously pregnant. Prominent scars were also recorded. Total length (TL; tip of snout to end of caudal fin) was estimated by (1) swimming alongside each shark and measuring length with a marked line, and using the mean of 3 measurements to reduce human error or (2) repeated observations of sharks swimming parallel to vessels of known size (Ramírez-Macías et al. 2007).

\section{Photo-identification}

The area used for identification of whale sharks is the spot-and-stripe pattern between the last gill slit and forward of the dorsal fin (Taylor 1994, Arzoumanian et al. 2005); we photographed this area with a waterproof digital camera. When possible, both the left and right sides were photographed. Images in our photograph library were separated for analysis based on gender (male, female, undetermined) and were compared by Interactive Individual Identification System software ( $\mathrm{I}^{3} \mathrm{~S}$ software; van Tienhoven et al. 2007), as further described by Speed et al. (2007). Capture history was based on photo-identification of images of the left side, because these were more common in the database than right-side images.

At each locality, new identifications were plotted over time in a discovery curve to illustrate the rate at which newly identified individuals were encountered.

For Bahía de Los Ángeles and Bahía de La Paz, the null hypothesis of frequency differences among gender classes over time (years and months) and localities was tested using the G-test of independence, used for likelihood ratio or maximum-likelihood statistical significance tests.

\section{Site fidelity}

Re-sighting events were tracked over time. The period of membership of individual sharks within each aggregation was determined by the presence or absence of each individual at any time during that aggregation season (Rowat et al. 2011).

To estimate the amount of time identified individuals reside in Bahía de Los Ángeles and Bahía de La Paz, we calculated the lag identification rate (LIR), which is the probability of identifying an individual given its identification some lag time earlier (Whitehead 2007). All LIR estimates were calculated using SOCPROG 2.3 software (Whitehead 2009). Two models of residency were fitted to the residency data using quasi-Akaike's information criterion (QAIC) methods to determine the best model. QAIC modelfitting was chosen over AIC model-fitting because of variance over dispersion (Whitehead 2007). The 2 models fitted were (1) a model that allows for emigration and re-immigration and (2) a model that allows for emigration, re-immigration, and mortality.

\section{Abundance}

We estimated seasonal abundance in Bahía de Los Ángeles (2008 and 2009) and Bahía de La Paz (2005 through 2009). After discarding photographs of poor quality (Speed et al. 2007), capture histories, consisting of seasonal re-sightings, were constructed using matches identified by $\mathrm{I}^{3} \mathrm{~S}$ software. Given our understanding of this species, we cannot assume that the population was closed during the study period. The interval of sampling was run every $2 \mathrm{wk}$ (Holmberg et al. 2009), using the Jolly-Seber open-population model (Schwarz \& Arnason 1996) in the POPAN option in the MARK software (White \& Burnham 1999). For $t$ capture occasions, the model provides $t-1$ estimates of $\varphi$ (apparent survival), $t$ estimates of $p$ (capture probability, given the animal is alive and available for capture), $t-1$ estimates of $\beta$ (probability of entry into the population per occasion), and $N$ (super-population size). Models were fitted using the logit link function for $\hat{\varphi}$ and $\hat{p}$, the identity link function for $\hat{N}$, and the multinominal logit link function to constrain the set of $\hat{\beta}$ parameters to $<1$ (otherwise, convergence can be problematic; White \& Burnham 1999). Estimates of $\varphi$, $p$, and $\beta$ were not developed under the full CormackJolly-Seber mark-capture framework, since estimating these parameters was not the main objective of the study (White \& Burnham 1999, Meekan et al. 2006, Rowat et al. 2009, Ramírez-Macías et al. 2012). 
An estimate of demographic parameters using open models is based on several assumptions: (1) all individuals possess unique markings and these are stable over time; (2) marks are not lost or missed; (3) every marked animal in the population at time $i$ has the same probability of recapture $\left(p_{i}\right)_{i}$ (4) every marked animal in the population immediately after time $i$ has the same probability of surviving to time $i+$ 1; and (5) all samples are instantaneous, relative to the interval between occasions $i$ and $i+1$, and each release is made immediately after the sample.

The first and second assumptions were addressed by using the spot pattern of whale sharks; each pattern is unique to each animal and is an effective marker for capture-mark-recapture studies (Taylor 1994, Arzoumanian et al. 2005). For the third and fourth assumptions, we used the program RELESE GOF as implemented in the MARK program (White \& Burnham 1999) to test for violations of the model assumption from heterogeneity in capture probability (Test 2) and survival (Test 3). Although the final assumption is never literally met in a wildlife study, the survey period should be short, relative to the survival interval. In this way, survival estimate intervals are of equal duration and there is a reduced chance of any mortality occurring within a re-sighting period. In our case, re-sighting effort was spread unevenly and at all times of the year, so that we could not use all the data without violating the instantaneous sampling assumption. Instead, we used only the re-sighting data from the same relatively intensive survey periods used to estimate abundance, and the sampling occasions selected for analysis were short in duration (2 wk).

\section{Movements between Bahía de Los Ángeles and Bahía de La Paz}

We sighted some whale sharks in both Bahía de Los Ángeles and Bahía de La Paz, so the analysis is of these 2 localities. We used the SOCPROG 2.3 software (Whitehead 2009) to estimate the probability that if an individual is identified in Bahía de Los Ángeles, it is identified in Bahía de La Paz at a later time and vice versa.

\section{RESULTS}

\section{Photo-identification}

At all localities, new Rhincodon typus individuals were steadily identified throughout the study (Fig. 2); the cumulative curve never reached an asymptote. We identified 251 whale sharks from 1784 photographs; of these, 129 sharks were identified in Bahía de Los Ángeles, 125 in Bahía de La Paz, 15 at Gorda Banks, and 8 at Isla Espíritu Santo. Of the 251 whale sharks, 26 sharks were seen in both Bahía de Los Ángeles and Bahía de La Paz.
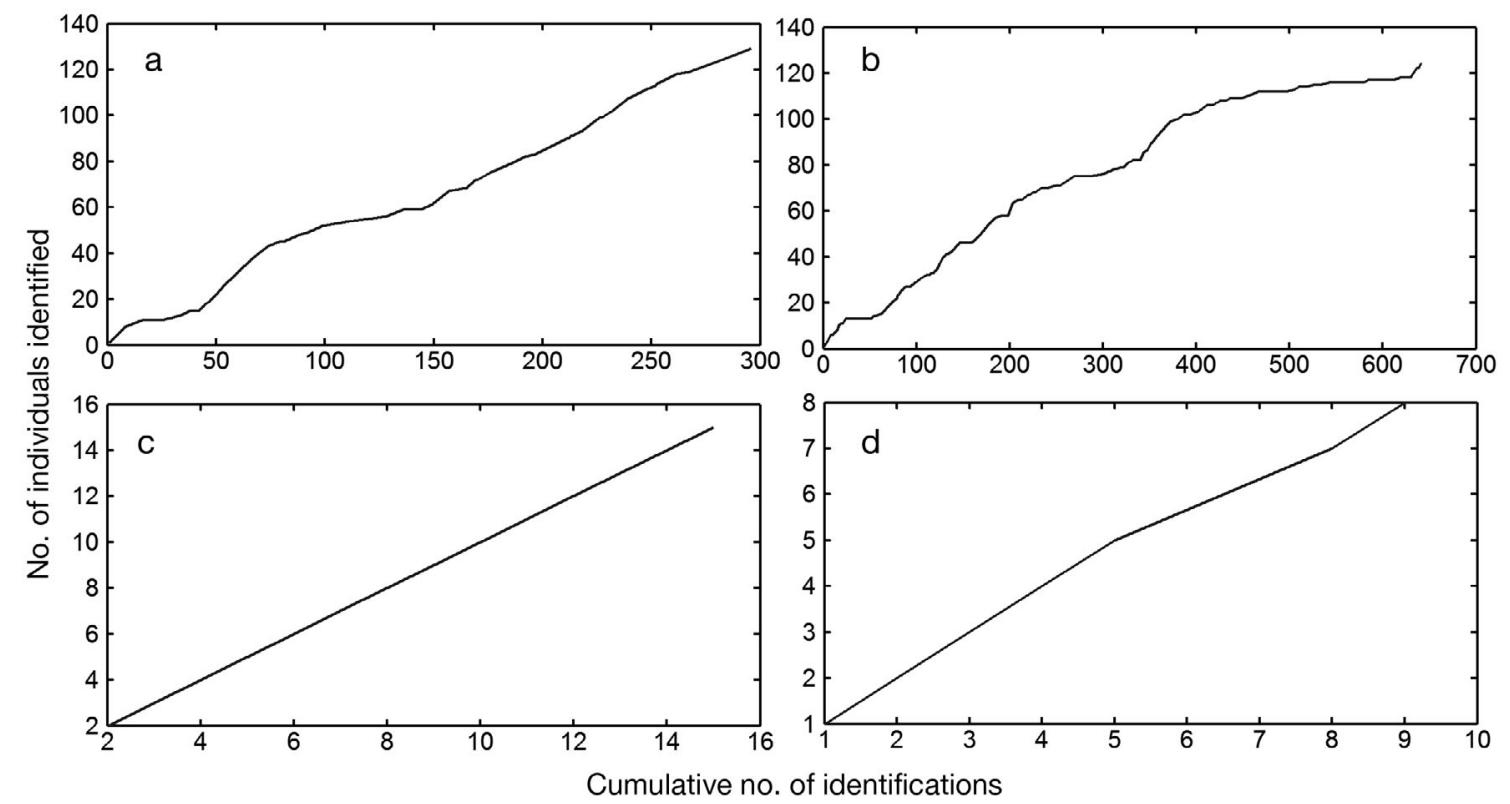

Fig. 2. Rhincodon typus. Cumulative number of identifications of new whale sharks against the cumulative number of all identifications: (a) Bahía de Los Ángeles, (b) Bahía de La Paz, (c) Gorda Banks, and (d) Isla Espíritu Santo 


\section{Population structure}

All sharks near the shore of Bahía de Los Angeles and Bahía de La Paz were juveniles, with the exception of 1 female (9 m) in 2009 in Bahía de los Ángeles. Only pregnant females were sighted in deep water around Gorda Banks and Isla Espíritu Santo (Fig. 3).

Of 129 sharks identified in Bahía de Los Angeles, $68.5 \%$ were male, $21.5 \%$ were female, and $10 \%$ were not determined; length ranged from 2.5 to $9 \mathrm{~m}$, with a mode of $5 \mathrm{~m}$ (Fig. 4).

Of 125 sharks identified in Bahía de La Paz, 69\% were male, $23 \%$ were female, and $8 \%$ were not
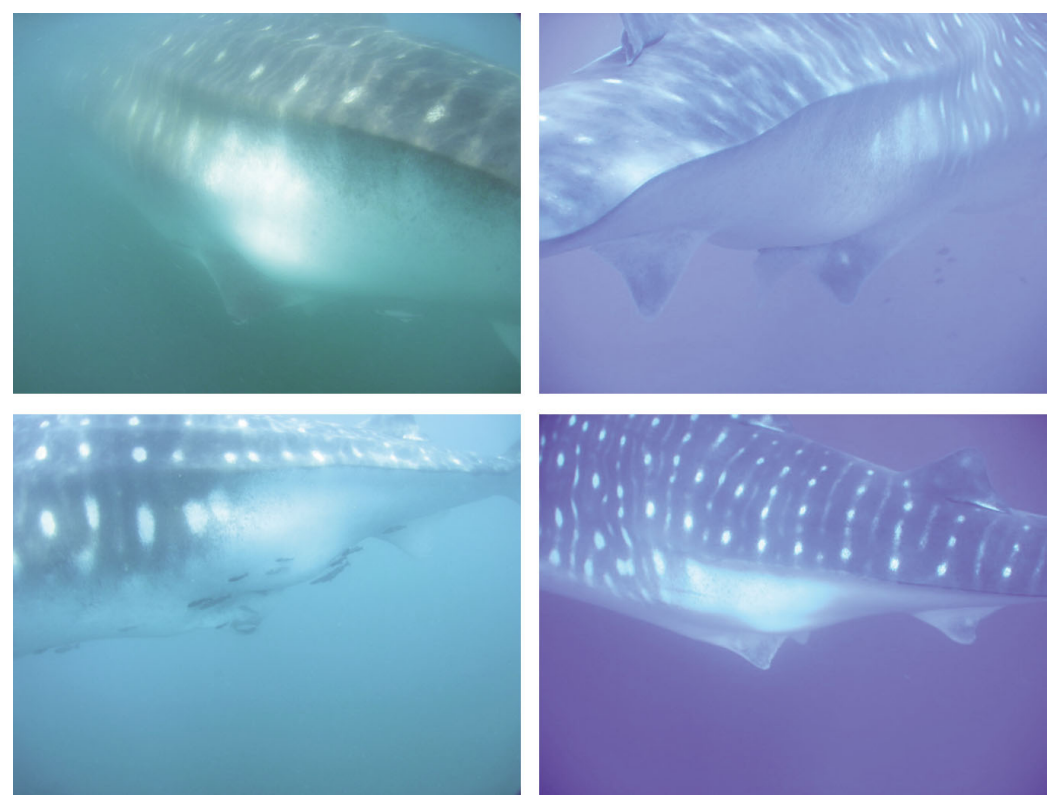

Fig. 3. Rhincodon typus. Distended bellies of pregnant female whale sharks

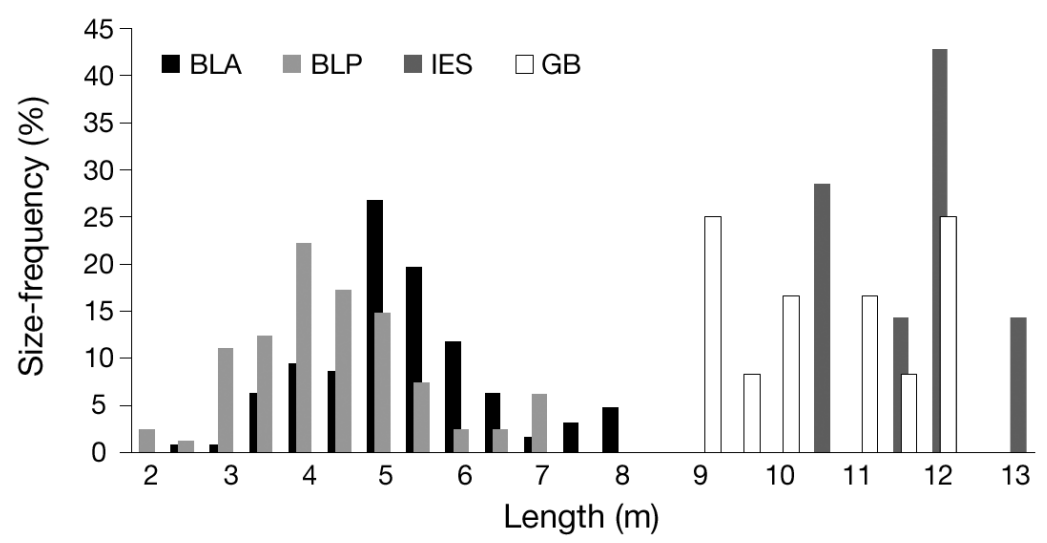

Fig. 4. Rhincodon typus. Size-frequency distribution of whale sharks observed in Bahía de Los Ángeles (BLA), Bahía de La Paz (BLP), Isla Espíritu Santo (IES), and Gorda Banks (GB) from 2003 through 2010, based on 220 photographed individuals determined; length ranged from 2 to $7 \mathrm{~m}$, with a mode at $4 \mathrm{~m}$ (Fig. 4). The male:female ratio at both sites was the same $\left(G_{1}=0.03, \mathrm{p}>0.86\right)$.

At Gorda Banks, 15 pregnant females were identified, ranging from 9 to $12 \mathrm{~m}$; at Isla Espíritu Santo, 8 pregnant females were identified, ranging from 9 to $13 \mathrm{~m}$ (Fig. 4)

\section{Site fidelity}

Of 129 identified sharks in Bahía de Los Ángeles, $64(49 \%)$ were subsequently re-identified at least once at this locality (Table 2). Of these, 16 (12\%) were re-sighted between years; the sex ratio of re-sighted sharks in multiple years did not differ from that of the original population $\left(G_{1}=0.003, \mathrm{p}>\right.$ $0.5)$. After excluding the 60 individuals that were seen for the first time in 2009, 69 remained. Of these, 53 were only seen in $1 \mathrm{yr}$, while 16 were resighted individuals, $12(75 \%)$ were seen in 2 consecutive years, and 4 $(25 \%)$ were seen 3 to $7 \mathrm{yr}$ later (Table 2). Of these last 4, 1 was seen in 3 consecutive years; the rest were seen 3,4 , or 7 yr apart. The mean elapsed time between re-sightings was $2.7 \mathrm{yr}$. The most frequent length of returning sharks was $6 \mathrm{~m}$, followed by $5 \mathrm{~m}$.

The LIR of whale sharks fell after lags of approximately 3 to $30 \mathrm{~d}$ and then leveled off above zero at longer time lags, although a few animals stayed up to $146 \mathrm{~d}$ (season up to $175 \mathrm{~d}$ ) (Fig. 5a). This pattern suggests that animals may spend periods of up to $30 \mathrm{~d}$ in the bay before leaving the study area. The LIR leveled off above zero, suggesting that some animals are permanent residents and/or others reimmigrate into the study area after longer time lags. Of the 2 models applied to the data, the model curve of emigration, re-immigration, and mortality in the study area fitted the data best (Fig. 5a). The maximum number of re-sightings for any identified shark was 10 , while the average number of re-sightings was 2.3, and the longest period between re-sighting events was $2220 \mathrm{~d}$. 
Table 2. Rhincodon typus. Summary of sightings of whale sharks in Bahía de Los Ángeles, based on photo-identification (left-side only). No sharks were observed in 2005. CI: confidence interval; SE: standard error

\begin{tabular}{|c|c|c|c|c|c|c|c|}
\hline & 2003 & 2004 & 2006 & 2007 & 2008 & 2009 & Total \\
\hline No. of surveys & 8 & 3 & 3 & 6 & 18 & 25 & 63 \\
\hline Identified sharks & 12 & 8 & 4 & 10 & 40 & 73 & 147 \\
\hline \multicolumn{8}{|c|}{ Re-sightings } \\
\hline 1 yr before & & 4 & 0 & 0 & 1 & 9 & 14 \\
\hline$\geq 2$ yr before & & 0 & 0 & 0 & 0 & 4 & 4 \\
\hline Total matched & & 4 & 0 & 0 & 1 & 13 & 18 \\
\hline New sharks & 12 & 4 & 4 & 10 & 39 & 60 & 129 \\
\hline Percent matched & & 50 & 0 & 0 & 2.5 & 17.8 & - \\
\hline Abundance & & & & & 54 & 94 & \\
\hline CI & & & & & $46-69$ & $84-110$ & \\
\hline SE & & & & & 5 & 6 & \\
\hline
\end{tabular}

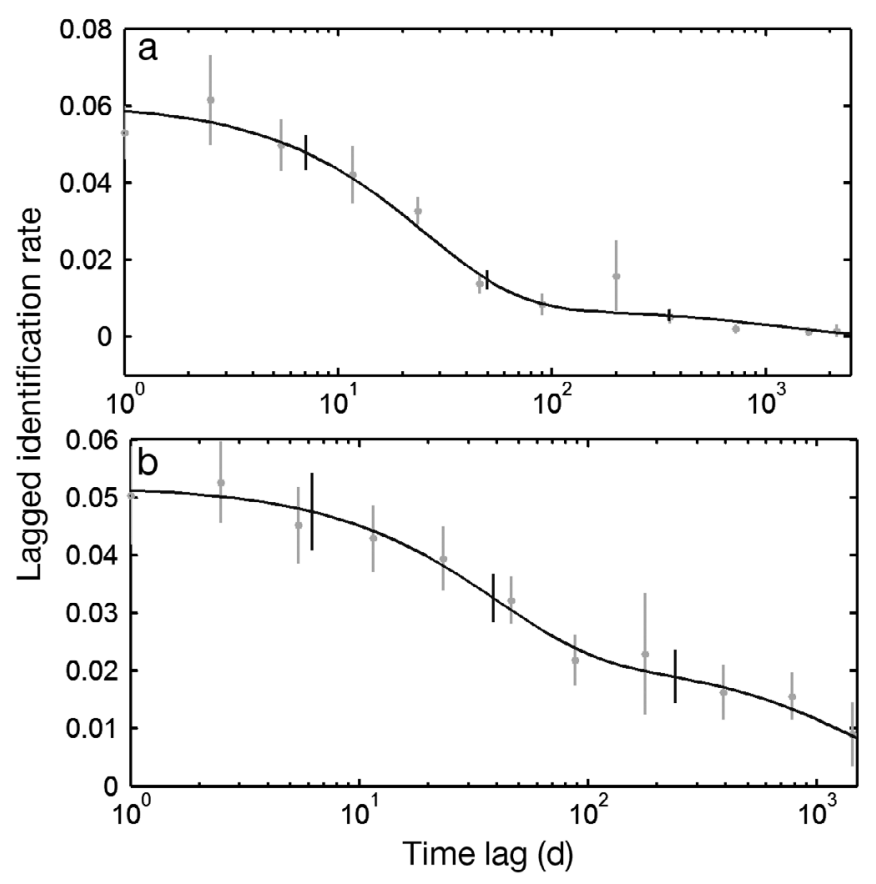

Fig. 5. Rhincodon typus. Lagged identification rate for whale sharks in coastal waters of (a) Bahía de Los Ángeles and (b) Bahía de La Paz, with the expected lagged identification rates (black bars) and estimated standard errors (error bars) from the emigration, re-immigration, and mortality model fitted to the data using maximum-likelihood statistics

Of the 125 sharks identified in Bahía de La Paz, 61 (49\%) were subsequently re-sighted at least once in the bay, including $22(17.6 \%)$ which were resighted between years; the sex ratio of re-sighted sharks in multiple years did not differ from that of the original population $\left(G_{1}=0.34, \mathrm{p}>0.5\right)$ (Table 3). Of the 125 identified sharks, 39 were identified for
Table 3. Rhincodon typus. Summary of sightings of whale sharks in Bahía de La Paz, based on photo-identification (left-side only). CI: confidence interval; SE: standard error

\begin{tabular}{|lcccccccc|}
\hline & 2004 & 2005 & 2006 & 2007 & 2008 & 2009 & Total \\
\hline No. of surveys & 6 & 31 & 8 & 13 & 29 & 53 & 134 \\
Identified sharks & 8 & 30 & 19 & 20 & 33 & 54 & 164 \\
Re-sightings & & & & & & & \\
$\quad 1$ yr before & & 5 & 3 & 3 & 2 & 6 & 19 \\
$\geq 2$ yr before & & & 3 & 4 & 4 & 9 & 20 \\
Total matched & & 5 & 6 & 7 & 6 & 15 & 39 \\
New sharks & 8 & 25 & 13 & 13 & 27 & 39 & 125 \\
Percent matched & & 16.7 & 31.6 & 35 & 18.2 & 27.8 & - \\
Abundance & & 36 & 19 & 20 & 33 & 62 & \\
CI & & $32-46$ & 19 & $26-3130-42$ & $58-72$ & \\
SE & & 3.32 & 0 & 2.51 & 2.47 & 3.41 & \\
\hline
\end{tabular}

the first time in 2009, leaving 86 sharks available for multiple-year sightings; 64 sharks were seen only once. Of the 22 that were re-sighted, 10 (45\%) were seen $2 \mathrm{yr}$ apart and the other $12(55 \%)$ were resighted between 3 and 6 yr apart. Of these 12, 3 were not seen in consecutive years; of the rest, 1 was re-sighted in 4 successive years, then was not seen in the next year, but was re-sighted in the sixth year. Another was seen in 2 successive years, did not appear in the third year, and then was sighted in the next 2 years. Another juvenile was re-sighted in 6 successive years. Other multiple-sightings included 4 sharks sighted 3 years in a row and 2 sighted 4 years in a row (Table 3 ). The mean period of the membership was 3 years. The most common total length of the returning sharks was $4 \mathrm{~m}$, followed by $3 \mathrm{~m}$.

The LIR of whale sharks fell after lags of approximately 3 to $60 \mathrm{~d}$ and then leveled off above zero at longer time lags (Fig. 5b). This pattern suggests that most animals spend periods of up to $60 \mathrm{~d}$ in the bay before leaving the study area, although a few animals may stay up to $153 \mathrm{~d}$. The LIR leveled off above zero, suggesting that some animals are permanent residents and/or others re-immigrate into the study area after longer time lags. Of the 2 models applied to the data, the model curve of emigration, re-immigration, and mortality in the study area fitted the data (Fig. 5b) The maximum number of resightings for any identified shark was 51 , while the average number of re-sightings was 5.19, and the longest period between re-sighting events was $1954 \mathrm{~d}$.

At Gorda Banks, no whale shark was re-sighted; at Isla Espíritu Santo, 2 (25\%) whale sharks were resighted at least once in the same season separated by days. 


\section{Abundance}

Our dataset did not fail the test for homogeneity of capture and survival probabilities (Test 2 and Test 3), yielding $\mathrm{p}$-values $>0.87$, but the data for Bahía de La Paz from 2007 were insufficient for this test; however, we know of no systematic behavior, such as significantly different residency times among marked individuals, that would cause intra-seasonal heterogeneity in capture probability while allowing capture probability for primary periods to remain homogeneous under the available tests (Holmberg et al. 2009).

Bahía de Los Ángeles. In 2008 and 2009, surveys were made during the season of aggregation, from August through November in 2008 and from May through November in 2009. In both years, October was the month of highest abundance (Fig. 6). There was no change in the female:male ratio during the years 2003, 2008, and $2009\left(G_{2}=1.91, \mathrm{p}>0.38\right)$ or months (2008: $G_{3}=1.92, \mathrm{p}>0.59 ; 2009: G_{5}=4.45$, p > 0.45; Fig. 6). Based on the open population models (POPAN option), in 2008, estimated abundance was 54 sharks $(95 \% \mathrm{CI}=46$ to $69, \mathrm{SE}=5)$; in 2009, estimated abundance was 94 sharks (95\% CI = 84 to 110, $\mathrm{SE}=6$ ) (Table 2).

Bahía de La Paz. Abundance during seasonal aggregations varied over the years (Fig. 7); there was no change in female:male ratios between years $\left(G_{3}=\right.$ 2.25, p > 0.68) or months (2005: $G_{4}=0.89, \mathrm{p}>0.90$; 2006: $G_{1}=0.14, \mathrm{p}>0.70 ; 2007: G_{1}=0.71, \mathrm{p}>0.39$; 2008: $G_{3}=1.14, \mathrm{p}>0.76 ; 2009: G_{4}=2.71, \mathrm{p}>0.60$; Fig. 7). Based on open population models (POPAN option), abundance during aggregation seasons ranged from $19(95 \%)$ to 62 (95\% CI = 58 to 72$)$ whale sharks (Table 3).
Isla Espíritu Santo. Surrounding this island, we sighted 1 to 5 pregnant females in May and June. There were no re-sightings of females between years.

Gorda Banks. We sighted 5 to 10 pregnant females between April and June. There were no re-sightings of pregnant females between years.

\section{Movements between Bahía de Los Ángeles and Bahía de La Paz}

During our field surveys, we photographed 129 juveniles in Bahía de Los Ángeles and 125 in Bahía de La Paz. Of these 254 juvenile sharks, 26 (11.40\%) moved between the 2 bays; the sex ratio of resighted sharks in multiple years did not differ from that of the original population $\left(G_{1}=0.12, \mathrm{p}>0.5\right)$. Eighteen moved from Bahía de Los Ángeles to Bahía de La Paz, 4 from Bahía de La Paz to Bahía de los Ángeles, 3 sharks did a round trip starting in Bahía de la Paz, moving to Bahía de Los Ángeles, and returning to Bahía de La Paz; 2 whale sharks did a round trip starting in Bahía de Los Ángeles, moving to La Paz, and returning to Bahía de Los Ángeles, and moving again to Bahía de La Paz (Fig. 8).

The data from 2008 and 2009 indicate the percentage of the individuals moving between these 2 localities. In 2008, of the 40 sharks identified in Bahía de los Ángeles, 7 (17.5\%) were re-sighted in Bahía de La Paz; and, in 2009, of 74 sharks, 12 (16.21\%) were re-sighted in Bahía de La Paz. In 2008, of the 33 sharks first identified at Bahía de La Paz, 7 (21.21\%) were re-sighted in 2009 in Bahía de Los Ángeles (Table 4).

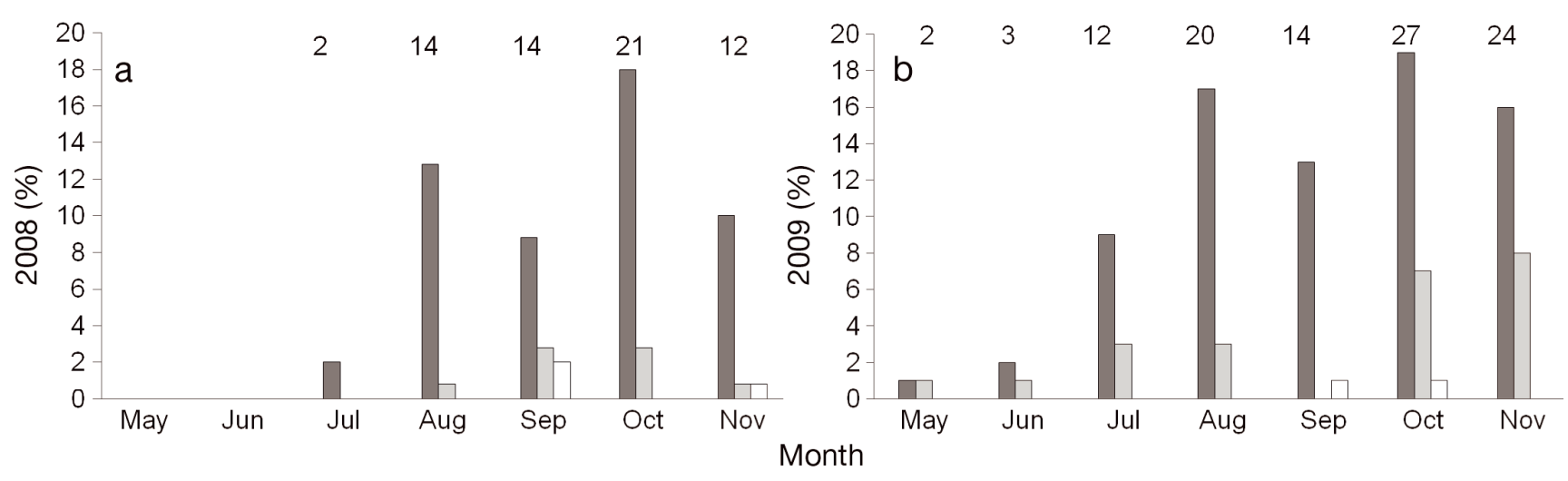

Fig. 6. Rhincodon typus. Juvenile whale sharks in Bahía de Los Ángeles in (a) 2008 and (b) 2009. Percentage of whale sharks by sex (dark grey: male; light grey: female; white: indeterminate) and by month, based on photo-identification. Above bars are the number of whale sharks photographed 

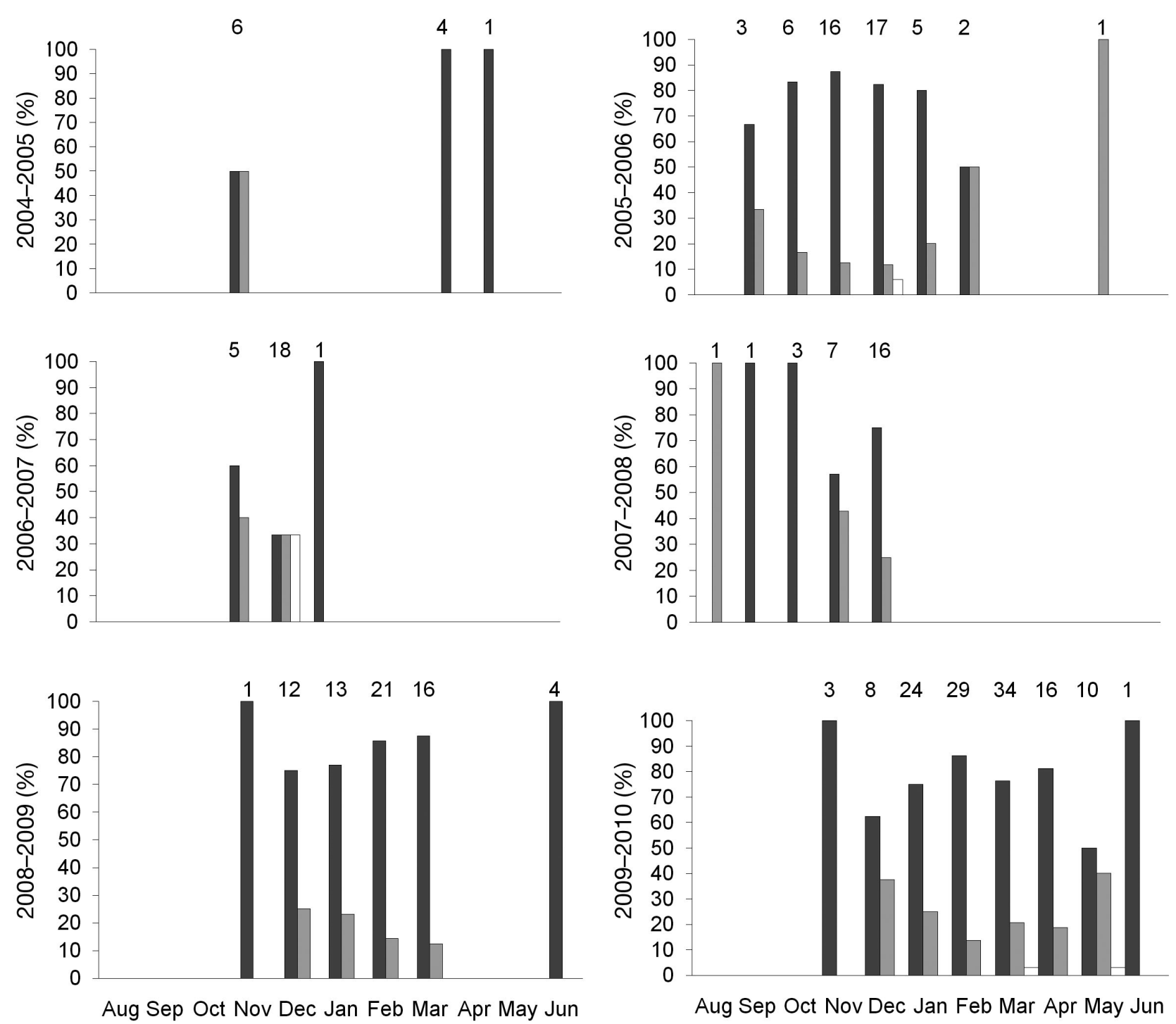

Fig. 7. Rhincodon typus. Juvenile whale sharks in Bahía de La Paz during 6 yr. Percentage of whale sharks by sex (dark grey: male; light grey: female; white: indeterminate) and by month, based on photo-identification. Above bars are the number of whale sharks photographed

The LIR of whale sharks that moved from Bahía de los Ángeles to Bahía de La Paz was highest after 20 to $100 \mathrm{~d}$ and then leveled off above zero at longer time lags (Fig. 9). This pattern suggests that the animals moved from Bahía de Los Ángeles to Bahía de La Paz in a period of 20 to $100 \mathrm{~d}$, although few animals were seen at La Paz after $248 \mathrm{~d}$. The LIR leveled off above zero, suggesting that some animals moved after longer time lags. The LIR of whale sharks that moved from Bahía de La Paz to Bahía de Los Ángeles was highest after 100 to $200 \mathrm{~d}$ and then leveled off above zero at longer time lags (Fig. 9). This pattern suggests that the animals moved from Bahía de La Paz to Bahía de Los Ángeles in a period of 100 to 200 d, although a few animals were seen in Bahía de Los Ángeles after $337 \mathrm{~d}$. The LIR leveled off above zero, suggesting that some animals moved after longer time lags.

\section{DISCUSSION}

With photo-identification, we identified individual whale sharks Rhincodon typus and monitored the general population at 4 sites, including re-sightings within and between years and localities. The number of re-sightings indicates some site fidelity of juveniles during the aggregation season. 

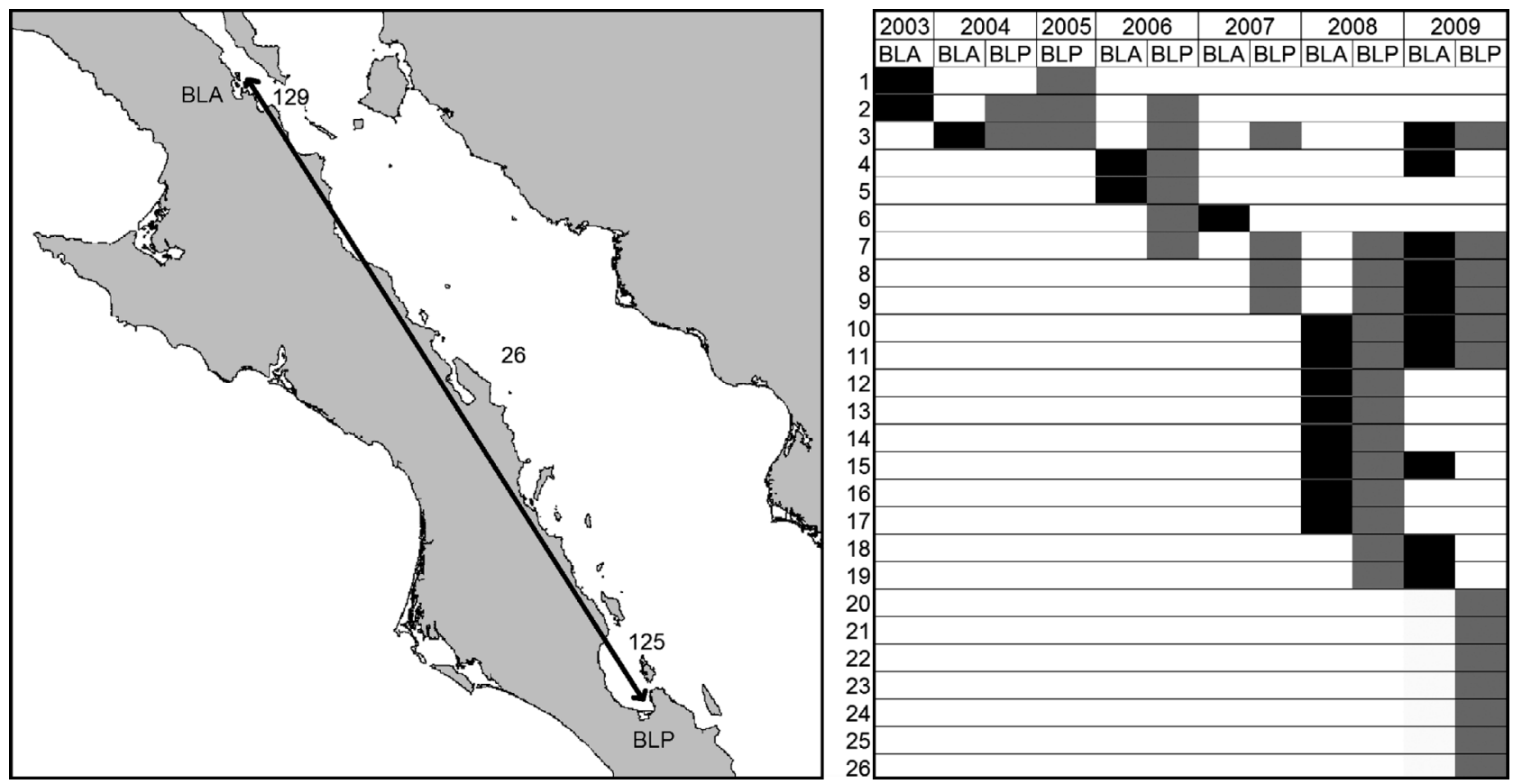

Fig. 8. Rhincodon typus. Time data for 26 whale sharks migrating between Bahía de Los Ángeles (BLA) and Bahía de La Paz (BLP). Values show the total number of whale sharks identified at BLA and BLP, and the number observed to migrate between the 2 sites

Table 4. Rhincodon typus. Summary of re-sightings of whale sharks, based on photo-identification. BLA: Bahía de Los Ángeles; BLP: Bahía de La Paz; BLA > BLP: whale sharks migrating from BLA to BLP in the same year; BLP > BLA: whale sharks migrating from BLP to BLA in the same or following year

\begin{tabular}{|lccccc|}
\hline & 2004 & 2006 & 2007 & 2008 & 2009 \\
\hline BLA & 8 & 4 & 10 & 40 & 73 \\
BLP & 8 & 19 & 21 & & 54 \\
BLA > BLP & 1 & 2 & 0 & 7 & 12 \\
BLA > BLP (\%) & & & & 17.5 & 16.4 \\
BLP > BLA & & & & & 7 \\
BLP > BLA (\%) & & & & & 21.0 \\
\hline
\end{tabular}

\section{Population structure}

Our data confirm that whale sharks in the Gulf of California segregate by size and sex. Juveniles aggregate in the shallower waters of Bahía de La Paz and Bahía de Los Ángeles. Pregnant females aggregate in deeper waters in the southern part of the Gulf of California (Eckert \& Stewart 2001, Ketchum 2003, Ramírez-Macías et al. 2007).

Of the juveniles sighted in the coastal waters of the 2 bays, the modal length of small (4 and $5 \mathrm{~m}$ ) sharks is similar to that of juveniles aggregating near Djibouti (Rowat et al. 2007), but contrasts with that of aggregations among the reefs of Belize, Australia,

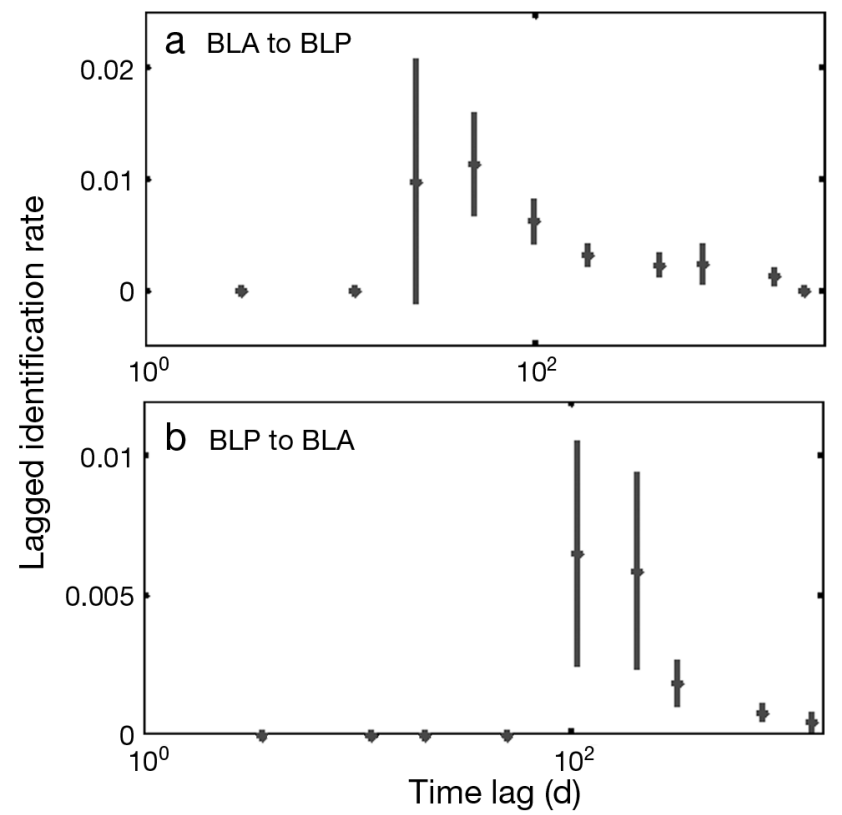

Fig. 9. Rhincodon typus. Lagged identification rate for whale sharks migrating from (a) Bahía de Los Ángeles (BLA) to Bahía de La Paz (BLP) and (b) vice versa

the Maldives, and the Gulf of Mexico, which are 6 to $7 \mathrm{~m}$ long (Meekan et al. 2006, Graham \& Roberts 2007, Riley et al. 2010, Ramírez-Macías et al. 2012).

Pregnant females (9 to $13 \mathrm{~m}$ ) aggregate in deeper, offshore areas in the southern part of the Gulf of Cal- 
ifornia; these females are considerably larger than females reported in most other localities. In the Galapagos, aggregations are composed of large $(9+\mathrm{m})$ pregnant females (Alex Antoniou, Shark Research Institude, pers. comm.). Large pregnant females have also been seen at Islas Revillagigedo $\left(18^{\circ} 49^{\prime} \mathrm{N}\right.$, $112^{\circ} 46^{\prime}$ W; D. Ramírez-Macías pers. obs.).

According to Rowat et al. (2008), juveniles $(<3 \mathrm{~m})$ are likely to remain fairly close to their birthing areas. The presence of very small sharks $(\sim 2 \mathrm{~m})$ in Bahía de La Paz and aggregations of pregnant females in southern waters of the Gulf of California suggest the presence of a nursery near the studied areas (Bahía de La Paz, Isla Espiritu Santo, and Gorda Banks), probably in deep waters (Ketchum 2003, Ramírez-Macías et al. 2007). In most cases, capture of whale shark neonates were in deep water, considerably deeper (2650 to $4750 \mathrm{~m}$ ) than the depth at which adult whale sharks aggregate (Wolfson 1983, Kukuyev 1995, Rowat et al. 2008, Aca \& Schmidt 2011).

Nursery areas for shark populations are regions where young are born or reside as they grow towards maturity. Different criteria have been used to identify these localities. Heupel et al. (2007) suggested using 3 primary criteria to identify newborn or young-ofthe-year individuals (i.e. <1 yr old): (1) sharks are more commonly encountered in the area than in other areas, i.e. density in the area is greater than the mean density over all areas; (2) sharks have a tendency to remain or return for extended periods (weeks or months), i.e. site fidelity is greater than the mean site fidelity for all areas; and (3) the area or habitat is repeatedly used across years, whereas others are not. The absence of whale shark neonates does not necessarily mean the absence of a nursery near the study areas.

According to Bass (1978), primary nursery areas are those where young sharks are actually born and spend the first part of their lives. Secondary nursery areas are inhabited by slightly older, but not yet adolescent sharks. Normally, juveniles find food and protection from predators. Some authors distinguish between protected and unprotected habitats, based on the presence or absence of predators (Branstetter 1990). Accordingly, the 2 bays are protected secondary nurseries.

The sex ratio in the 2 bays is similar, about $3: 1$ in favor of males. Male-biased sex ratios among juveniles appear typical of aggregations worldwide (Meekan et al. 2006, Graham \& Roberts 2007, Rowat et al. 2007). The movements of adult males (>8 m) remain unknown; they appear to leave the Gulf of
California because no adult male was sighted during the field surveys.

Segregation by sex or biased sex ratios have long been recognized as typical patterns of some shark species (Springer 1967, Klimley 1987, Robbins 2007). Such behavior may be a consequence of intra-specific competition for food or mates or reproductive strategies associated with mating behavior, seasonal habitat, or resource requirements (Sims et al. 2001). Biased sex ratios may also be related to migration patterns (Pratt 1979). Our findings suggest that different age classes and sexes undertake migrations related to their age and sex, as has been found at other localities and for other shark species (Pratt 1979).

\section{Site fidelity}

Using photo-identification, we found that only juveniles exhibited site fidelity. In contrast, no pregnant female was re-sighted in subsequent years. Only 1 pregnant female was re-sighted during the same season, only a few days later. In summary, the surveys suggest that adults undertake longer migrations than do juvenile sharks.

Our data show that inter-annual site fidelity of juveniles in Bahía de La Paz (16 to 35\%) and Bahía de Los Ángeles (2.5 to $50 \%$ ) is higher than that of the population at the Seychelles (15 to $23 \%$; Rowat et al. 2009) and Holbox Island (11 to 27 \% ; Ramírez-Macías et al. 2012), although the mean of the aggregation membership period was lower than at the Seychelles (3.4 yr). Perhaps this reflects the longer monitoring period of the program at the Seychelles. The mean of the aggregation membership period in Bahía de Los Ángeles (2.7 yr) was the same as that reported for Ningaloo (2.7 yr; Meekan et al. 2006). Membership in Bahía de La Paz (3 yr) was higher than that at Dijibouti (2.9 yr) and lower than that at the Seychelles (3.4 yr; Rowat et al. 2011). The differences between these localities could be related to differences in sighting effort. For example, during the last 2 years, the monitoring program in Bahía de Los Ángeles included the entire season; this might affect the results, as discussed by Rowat et al. (2011) for Djibouti and Seychelles aggregations. What is consistent among all aggregations is the degree of inter-annual site fidelity, sometimes lasting decades, whereas other places are recorded only once as aggregation sites, at least over the duration of the present study.

In the Bahía de La Paz, the aggregation includes small juveniles, which are the ones that show fidel- 
ity to the area, although the membership period was calculated ignoring any missing re-sightings during the intervening period. These data showed that most re-sightings were in consecutive years, with a maximum of 6 consecutive years, which appears to be different from other aggregations. This could be related to the necessities of survival of small sharks. The Bahía de La Paz provides food and protection against predators.

In the Bahía de La Paz, bite scars were low (5\%; D. Ramírez-Macías unpubl. data) relative to bite scars on whale sharks in the Indian Ocean (Speed et al. 2008). Large predatory sharks were rarely seen in field or aerial surveys during the aggregation season. We observed only 1 mako Isurus oxyrinchus and 1 group of orcas Orcinus orca during our surveys (D. Ramírez-Macías unpubl. data). This may represent a generally low abundance of predators or that predation is low in the Bahía de La Paz, suggesting this bay is an important secondary nursery and habitat for juvenile whale sharks. It is difficult to quantify successful predation events outside the bays because victim will have been eaten.

Most individual sharks identified in the 2 bays do not reside in the study area permanently, but use the study area regularly from year to year. The large proportion of whale sharks observed only once $(51 \%)$ in both bays indicates that a high number of individuals either die or spend most of their time outside the study area in offshore or adjacent waters. Modeling of sighting patterns suggested that movement patterns of most individuals in both bays followed a model of emigration, re-immigration, and mortality in the study area. The coastal waters of the 2 bays appear to be an important area in the home ranges of whale sharks.

\section{Abundance}

The population of whale sharks utilizing the east coast of the Baja California Peninsula as aggregation sites consisted of at least 251 individuals, and the rate of identification of new individuals showed no sign of leveling off, suggesting that the overall population is much larger than all individuals identified.

In both bays, aggregations are related to high zooplankton abundance (copepods). Nelson \& Eckert (2007) report that juveniles in Bahía de los Ángeles feed on zooplankton where the density ranges from 1000 to 8700 ind. $\mathrm{m}^{-3}$. Hacohen-Domené et al. (2006) report zooplankton densities from 26800 to 83800 ind. $\mathrm{m}^{-3}$ in Bahía de La Paz.
Estimated annual abundance of juvenile whale sharks ranges from 19 to 58-72 in Bahía de La Paz and from 46-69 to 84-110 in Bahía de Los Ángeles. Seasonal abundance in both bays is smaller than the abundance at Ningaloo Reef, Australia (90-120 to 127-190 sharks, using open population models; Holmberg et al. 2009).

Aggregation size in some years differed. In 2003, in Bahía de La Paz, we encountered only 3 sharks (photographs of poor quality) and, in 2005, in Bahía de Los Ángeles, there were a few sightings, but not during our field work. In some years, pregnant females do not appear at Gorda Banks or Isla Espíritu Santo (Table 1). Wilson et al. (2001) show that changes in oceanographic conditions at Ningaloo Reef affect the number of whale sharks. According to Ketchum (2003) distinct seasonal and interannual variations in abundance during the period from 1995 to 2002 were linked to seasonal dynamics in Bahía de La Paz and inter-annual changes and anomalies of oceanographic patterns in the Gulf of California. For example, in 2003, zooplankton in Bahía de La Paz was low, but, in 2005, the concentration was high. In 2006, we sighted only 4 sharks in Bahía de Los Ángeles, apparently related to the low concentration of zooplankton. We did not survey Gorda Banks in 2008 and 2009 because local fishermen did not report sightings.

Because whale sharks in the Gulf of California represent a single population (Ramírez-Macías et al. 2007), changes in numbers in 1 bay likely reflect a change in distribution between other bays or aggregation sites rather than a change in population size. For this reason, assessing the status and dynamics of the population requires monitoring several aggregation sites.

In shallow waters of $\sim 20 \mathrm{~m}$ in Bahía de La Paz, seasonal aggregations have changed, probably linked to changes in oceanographic conditions. Juveniles previously aggregated from August through November (Wolfson 1987, Clark \& Nelson 1997, Ketchum 2003). In recent years, they have aggregated from November through March or April (Fig. 7). Apparently the seasonality of the high zooplankton abundance has changed, since food was absent during field observations in August through October 2008, but was present from November through March (Fig. 7); copepods were present at the beginning of the season and chaetognaths in the middle of the season, but no samples were collected. While the seasonality in Bahía de Los Angeles is similar, as reported by Cardenas-Torres et al. (2007), October is the month with more whale sharks. 
The pregnant female aggregations at Isla Espiritu Santo may also be related to high zooplankton abundance of the euphausiid Nyctiphanes simplex and of gastropod larvae (Ketchum 2003); only in 2009 were 3 pregnant females feeding. At Gorda Banks no pregnant females were feeding; the data suggest an absence of high concentrations of food, which is probably the reason whale sharks do not stay for a long period of time in the area.

\section{Movements between Bahía de Los Ángeles and Bahía de La Paz}

Photo-identification matches provide evidence that juvenile sharks from the study site are capable of moving between the 2 bays, with a distance between these bays of $700 \mathrm{~km}$. The 3 sharks that completed round trips were tracked a total of $2100 \mathrm{~km}$, and one was tracked for $2800 \mathrm{~km}$, going back and forth between the 2 bays. The data also show that $\sim 20 \%$ of the juveniles spent a long time in the Gulf of California. In the hypothetical case that sharks showing movements between the 2 bays did not leave the Gulf of California, the maximum number of days spent was 2004 and the minimum was 71, with a mean of 476 days. Although Whale Sharks 1, 2, 3, 4, 7, 8, and 9 (Fig. 8) did not show movements in all years, if we take into account only the years in which movements took place between the 2 bays, the maximum number of days spent was 523 and the minimum was 71, with a mean of 267 days.

The 2008 and 2009 field data for May through November suggest that many juvenile whale sharks aggregate to feed in Bahía de Los Ángeles and then migrate to Bahía de La Paz to feed. We do not know where they go after leaving Bahía de La Paz. A few originally found in Bahía de La Paz appear in Bahía de Los Ángeles, but they take longer to make the northward journey. In both bays we found whale sharks returning to just 1 bay in consecutive years and did not detect movement to the other bay, but caution should be taken when interpreting these results because effort was not continuous and individuals could have been present in the study area when surveys were not conducted.

There may be other locations in the Gulf of California where juveniles aggregate to feed. Other places reported to have whale shark aggregations are Bahía San Luis Gonzaga and Bahía de Las Animas (Eckert \& Stewart 2001). Several tour operators and fisherman have reported whale sharks traveling in Cabo Pulmo and occasionally at Guaymas, Loreto, and San
Jorge; sharks also travel out of the Gulf of California, with short aggregations reported at the San Blass Nayarit, Salina Cruz Oaxaca, (tour operators, fishermen), and the Revillagigedo Islands (D. RamírezMacías pers. obs.). Migration patterns and connections to other areas await long-term tracking studies.

\section{Implications for conservation}

Small populations are more prone to extinction than large, stable populations because of loss of genetic variability and environmental and demographic stochasticity (Caughley \& Gunn 1996). Although it is difficult to be certain about the status of whale sharks in the Gulf of California, our results for the study areas indicate that, at least at a local scale, the population is small. Although our abundance estimations are per season, the numbers of identified sharks are much lower than at other localities (i.e. in Bahía de La Paz, we identified 125 sharks in 6 yr; in Dijibouti, 297 whale sharks were identified in 8 yr; Rowat et al. 2011).

The estimates raise concern about the long-term survival of whale sharks in this region and emphasize the need to increase research and conservation efforts in the Gulf of California if conservation is to be successful. The low population numbers of whale sharks and our inability to detect trends reinforce the assertions that scientific proof of decline or increase should not be a necessary criterion for enacting conservation measures.

As individuals spend considerable time outside the study area, management strategies aimed at conserving whale sharks must include human activities in surrounding areas as well. The current levels of protection offered to whale sharks in Bahía de Los Ángeles and at Isla Espíritu Santo are better than in Bahía de La Paz and at Gorda Banks. Bahía de Los Ángeles and waters surrounding the Isla Espíritu Santo are protected areas. A similar designation for Bahía de La Paz and Gorda Banks would enhance regional whale shark conservation, offering young whale sharks and pregnant females protection.

Bahía de La Paz and Los Cabos (Gorda Banks) are the most highly populated coastal areas in the Gulf of California (215 178 and 138251 inhabitants, respectively); these areas also have the highest growth rate in the state of Baja California Sur, with an overall average annual growth rate of $2.6 \%$ over the past 5 yr (www.inegi.org.mx). In Bahía de La Paz small sharks aggregate near the city (Fig. 10), in waters increasingly affected by pollution and boat traffic. 


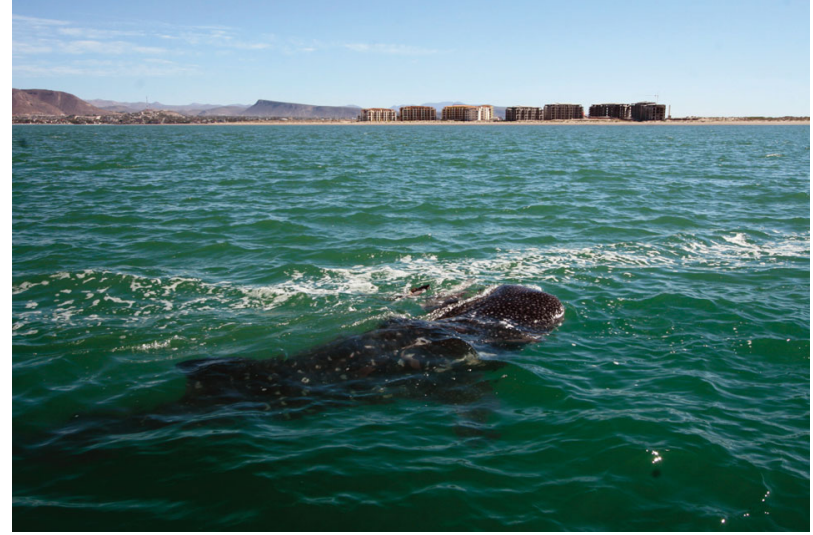

Fig. 10. Rhincodon typus. Juvenile whale shark feeding offshore near the city of La Paz. Mexico. Apartment blocks are on the El Mogote sand spit, which created the lagoon (Ensenada de La Paz); the peninsular mainland is on the far side of the lagoon. Photo: Carlos Aguilera

Given the small population sizes of whale sharks at these localities, efforts to maintain viable populations will require improvements to current levels of protection inside, as well as adjacent to, these areas. Such protection must involve not only the management of tourist activities, for example, instituting a code of conduct for whale shark tour operators, which has been enforced in Bahía de La Paz since 2006. Inspection is also needed because, during the aggregation season, up to $67 \%$ of the sharks are hit by boats (D. Ramírez-Macías unpubl. data). In a protected area it will be necessary to limit boats and manage gillnetting and other human activities along the coast that can pose a potential threat (pollution, mangrove destruction, vessel traffic).

Using different tools, including tagging of juveniles as resident or transient, as well as adults, and continuity of the monitoring program in sites in the Gulf of California should provide a better understanding of whale shark population dynamics in the Gulf of California. In the meantime, it is necessary to protect the critical habitats of this threatened shark by instituting a string of protected areas in the Gulf of California.

Acknowledgements. We thank the operators of the whale shark tourist industry in Bahía de Los Ángeles for their help during the monitoring program. A. Barnet provided insightful advice about the analysis. Field work was provided by P. Ahuja, C. Aguilera, P. Godoy, F. Morales, A. Hacohen, and S. Velázquez. Some pictures were provided by N. CárdenasTorres in Bahía de los Ángeles and A. Antoniou in Bahía de La Paz. We thank H. Peckham and J. Brunnschweiler for their suggestions for improving the manuscript. I. Fogel of CIBNOR provided editorial improvements. This project was funded by SEMARNAT-CONACYT (Grant FOSEMARNAT-
2004-01-457), Save Our Seas Foundation, PRODERS, and PROCODES (grants from CONANP). D.R.M. is a recipient of a fellowship from Consejo Nacional de Ciencia y Tecnología.

\section{LITERATURE CITED}

Aca EQ, Schmidt J (2011) Revised size limit for viability in the wild: neonatal and young of the year whale sharks identified in the Philippines. Asia Life Sci 20:361-367

Arzoumanian Z, Holmberg J, Norman B (2005) An astronomical pattern-matching algorithm for computer-aided identification of whale sharks Rhincodon typus. J Appl Ecol 42:999-1011

Bass AJ (1978) Problems in studies of sharks in the southwest Indian Ocean. In: Hodgson ES, Mathewson RF (eds) Sensory biology of sharks, skates and rays. ONR, Department of the Navy, Arlington, VA, p 545-594

Branstetter S (1990) Early life-history implications of selected carcharhinoid and lamnoid sharks of the Northwest Atlantic. In: Pratt HL Jr, Gruber SH, Taniuchi T (eds) Elasmobranchs as living resources: advances in biology, ecology, systematics and the status of the fisheries. NOAA Tech Rep 90, National Marine Fisheries Service, Silver Spring, MD, p 17-28

Cárdenas-Torres N, Enríquez-Andrade R, RodríguezDowdell N (2007) Community-based management through ecotourism in Bahia de los Angeles, Mexico. Fish Res 84:114-118

Caughley G, Gunn A (1996) Conservation biology in theory and practice. Blackwell Science, Oxford

CITES (Convention on International Trade in Endangered Species) (2002) Proposal to include the whale shark (Rhincodon typus). In: Appendix II, Convention on International Trade in Endangered Species (CITES). The Philippines and India to the 12th Conference of Parties to CITES. Available at: www.cites.org (accessed July 2009)

Clark E, Nelson D (1997) Young whale shark, Rhincodon typus, feeding on a copepod bloom near La Paz, México. Environ Biol Fish 50:63-73

Colman JG (1997) A review of the biology and ecology of the whale shark. J Fish Biol 51:1219-1234

Compagno LJ (1984) FAO species catalogue, Vol 4. Sharks of the world: an annotated and illustrated catalogue of shark species known to date, Part 1. Hexanchiformes to Lamniformes. FAO Fish Synop 125:209-211

DOF (2002) Diario Oficial de la Federación, 6 de marzo de 2002. T (582:4). México, D.F., p 1-80

Eckert SA, Stewart BS (2001) Telemetry and satellite tracking of whale sharks, Rhincodon typus, in the Sea of Cortez, Mexico and the North Pacific Ocean. Environ Biol Fishes 60:299-308

> Graham RT, Roberts CM (2007) Assessing the size and structure of a seasonal population of whale sharks (Rhincodon typus Smith, 1828) using conventional tagging and photo identification. Fish Res 84:71-80

Hacohen-Domené A, Galván-Magaña F, Ketchum-Mejía JT (2006) Abundance of whale shark (Rhincodon typus) preferred prey species in the southern Gulf of California, México. Cybium 30:99-102

Heupel MR, Carlson JK, Simpfendorfer CA (2007) Shark nursery areas: concepts, definition, characterization and assumptions. Mar Ecol Prog Ser 337:287-297

> Holmberg J, Norman BM, Arzoumanian Z (2008) Robust comparable population metrics through collaborative 
photomonitoring of whale sharks Rhincodon typus. Ecol Appl 18:222-233

Holmberg J, Norman BM, Arzoumanian Z (2009) Estimating population size, structure, and residency time for whale sharks Rhincodon typus through collaborative photoidentification. Endang Species Res 7:39-53

Joung SJ, Chen CT (1995) Reproduction in the sandbar shark, Carcharhinus plumbeus, in the waters of northeastern Taiwan. Copeia 1995:659-665

Ketchum JT (2003) Distribución espacio-temporal y ecología alimentaria del Tiburón ballena (Rhincodon typus) en la Bahía de la Paz y zonas adyacentes en el Suroeste del Golfo de California. Master's thesis, Centro Interdisciplinario de Ciencias Marinas-IPN, La Paz

Klimley AP (1987) The determinants of sexual segregation in the scalloped hammerhead shark, Sphyrna lewini. Environ Biol Fishes 18:27-40

Kukuyev EI (1995) The new finds in recently born individuals of the whale shark Rhincodon typus (Rhiniodontidae) in the Atlantic Ocean. J Ichthyol 36:279-281

Meekan MG, Bradshaw CJA, Press M, McLean C, Richards A, Quasnichka S, Taylor JG (2006) Population size and structure of whale sharks Rhincodon typus at Ningaloo Reef, Western Australia. Mar Ecol Prog Ser 319:275-285

Nelson J, Eckert S (2007) Foraging ecology by whale sharks (Rhincodon typus) within Bahia de los Angeles, Baja California Norte, Mexico. Fish Res 84:47-64

> Norman BM, Stevens JD (2007) Size and maturity status of the whale shark (Rhincodon typus) at Ningaloo Reef in Western Australia. Fish Res 84:81-86

Pratt H (1979) Reproduction in the blue shark, Prionace glauca. Fish Bull 77:445-470

- Ramírez-Macías D, Vázquez-Juárez R, Galván-Magaña F, Munguía-Vega A (2007) Variations of the mitochondrial control region sequence in whale sharks (Rhincodon typus) from the Gulf of California, Mexico. Fish Res 84: 87-95

Ramírez-Macías D, Meekan M, de la Parra-Venegas R, Remolina-Suárez F, Trigo-Mendoza M, Vázquez-Juárez R (2012) Patterns in composition, abundance and scarring of whale sharks Rhincodon typus near Holbox Island, Mexico. J Fish Biol 80:1401-1416

> Riley MJ, Hale MS, Harman A, Rees RG (2010) Analysis of whale shark Rhincodon typus aggregations near South Ari Atoll, Maldives Archipelago. Aquat Biol 8:145-150

$>$ Robbins RL (2007) Environmental variables affecting the sexual segregation of great white sharks Carcharodon carcharias at the Neptune Islands, South Australia. J Fish Biol 70:1350-1364

Rowat D, Meekan MG, Engelhardt U Pardigon B, Vely M (2007) Aggregation of juvenile whale shark (Rhincodon typus) in the Gulf of Tadjoura, Djibouti. Environ Biol Fishes 80:465-472

Rowat D, Gore M, Baloch BB, Islam Z and others (2008) New records of neonatal and juvenile whale sharks (Rhincodon typus) from the Indian Ocean. Environ Biol Fishes 82:215-219

Rowat D, Speed CD, Meekan MG, Gore MA, Bradshaw CJA (2009) Population abundance and apparent survival of the vulnerable whale shark Rhincodon typus in the Seychelles aggregation. Oryx 43:591-598

Editorial responsibility: Cornelius Hammer, Rostock, Germany
Rowat D, Brooks K, March A, McCarten C and others (2011) Long-term membership of whale sharks (Rhincodon typus) in coastal aggregations in Seychelles and Djibouti. Mar Freshw Res 62:621-627

Schwarz CJ, Arnason AN (1996) A general methodology for the analysis of open-model capture recapture experiments. Biometrics 52:860-873

- Sims DW, Nash JP, Morritt D (2001) Movements and activity of male and female dogfish in tidal sea lough: alternative behavioural strategies and apparent sexual segregation. Mar Biol 139:1165-1175

- Speed CW, Meekan MG, Bradshaw CJA (2007) Spot the match - wildlife photo-identification using information theory. Front Zool 4:2

Speed CW, Meekan MG, Rowat D, Pierce SJ, Marshall AD, Bradshaw CJA (2008) Scarring patterns and relative mortality rates of Indian Ocean whale sharks. J Fish Biol 72:1488-1503

Springer S (1967) Social organisation of shark populations. In: Gilbert PW, Mathewson RF, Rall DP (eds) Sharks, skates and rays. Johns Hopkins Press, Baltimore, MD, p 149-174

> Stevens JD (2007) Whale shark (Rhincodon typus) biology and ecology: a review of the primary literature. Fish Res $84: 4-9$

Taylor JG (1994) Whale sharks, the giants of Ningaloo Reef. Angus \& Robertson, Sydney

> van Tienhoven AM, den Hartog JE, Reijns R, Peddemors VM (2007) A computer-aided program for patternmatching of natural marks of the spotted ragged-tooth shark Carcharias taurus. J Appl Ecol 44:273-280

- White GC, Burnham KP (1999) Program MARK: survival estimation from populations of marked animals. Bird Study 46(Suppl):120-121

> Whitehead H (2001) Analysis of animal movement using opportunistic individual identifications: application to sperm whales. Ecology 82:1417-1432

Whitehead H (2007) Selection of models of lagged identification rates and lagged association rates using AIC and QAIC. Comm Statist Simulation Comput 36:1233-1246

Whitehead H (2009) SOCPROG programs: analysing animal social structures. Behav Ecol Sociobiol 63:765-778

Wilson SG, Taylor JG, Pearce AF (2001) The seasonal aggregation of whale sharks at Ningaloo Reef, Western Australia: currents, migrations and the El Niño/Southern oscillation. Environ Biol Fishes 61:1-11

Wintner SP (2000) Preliminary study of vertebral growth rings in the whale shark, Rhincodon typus, from the east coast of South Africa. Environ Biol Fishes 59:441-451

Wolfson FH (1983) Records of seven juveniles of the whale shark, Rhincodon typus. J Fish Biol 22:647-655

Wolfson FH (1986) Occurrences of the whale shark, Rhincodon typus Smith. In: Uyeno T, Arai R, Taniuchi T, Matsuura $\mathrm{K}$ (eds) Indo-Pacific fish biology: proceedings of the 2nd international conference on Indo-Pacific fishes. Ichthyological Society of Japan, Tokyo, p 208-226

Wolfson FH (1987) The whale shark, Rhincodon typus Smith, 1828, off Baja California, México (Chondrichthyes: Rhincodontidae). In: Mem V Simp Biol Mar, Vol 5. Universidad Autónoma de Baja California Sur, La Paz, p 103-110

Submitted: January 5, 2012; Accepted: May 8, 2012

Proofs received from author(s): July 25, 2012 